\title{
生体内熱移動方程式に関する一考察*
}

\author{
高 津 康 幸*1, 増 岡 隆 士*2
}

\section{Modeling of Bio-Heat Equation}

\author{
Yasuyuki TAKATSU*3 and Takashi MASUOKA \\ ${ }^{* 3}$ Department of Mechanical Engineering, Kure College of Technology, \\ 2-2-11 Agaminami, Kure-shi, Hiroshima, 737-8506 Japan
}

\begin{abstract}
A theoretical study has been made on the transport phenomena of the blood flow in the human body. To develop a discussion about the enthalpy transport in the bio-heat equation, we will need the information about a velocity field of blood flow. Therefore, we have proposed a bio-heat equation along with bio-continuity and momentum equations. With the aid of a local volume averaging, the macroscopic governing equations are derived from the microscopic governing equations, where the flow in the arterial and venous blood vessels is treated as one-dimensional pipe flow and the flow in the capillary blood vessels is approximated as the flow through porous media. Furthermore, we examine the boundary condition at the interface between the fluid and porous layers, and clarify the mechanism of the interfacial heat transfer between the artery (or vein) and the tissue.
\end{abstract}

Key Words: Biological Components and Systems, Governing Equation, Bio-Heat Equation, Pipe Flow, Porous Media, Boundary Condition

\section{1. 緒言}

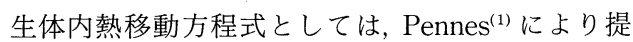
案されたものが広く用いられている。

$$
\rho_{t} c_{t} \frac{\partial T}{\partial t}=\lambda_{t} \nabla^{2} T+\rho_{b} c_{b} w_{b}\left(T_{a}-T\right)+Q
$$

ここで, $T$ : 組織温度, $T_{a}$ : 動脈温度, $w_{b}$ : 組織単位 体積あたりの血液流量である. Pennesの式において は, 血液潅流によるエンタルピ輸送を等方発熱項とし て取り扱う簡便な生体内熱移動方程式であるが，血管 幾何構造や潅流について詳細には議論していない。一 方, Weinbaum-Jiji ${ }^{(2)}$ は, 対向流による熱交換の概念 を導入し，血流潅流によるエンタルピ輸送項に対し非 等方的な取り扱いならびに非等方な見かけの熱伝導率 を用いた定式化を行い, Pennesの式の改良を試みて いる.しかしながら, Weinbaum-Jijiにより提案され た生体内熱移動方程式を解くためには血管網の幾何形 状が既知である必要があり, 実用的な方程式とは言い 難い. また, 横山(3) は, 動脈系および静脈系小プール

* 原稿受付 2007 年 11 月 5 日.

$* 1$ 正員, 呉工業高等専門学校機械工学科(恶 737-8506 呉市阿 賀南 2-2-11).

*2 正員, フェロー, 北九州市立大学国際環境工学部( $808-$ 0135 北九州市若松区ひびきの 1-1).

E-mail : takatsu@kure-nct.ac.jp
という概念を導入した生体内熱移動方程式を提案して いるが, 式中に含まれる熱伝達率を規定するまでには 至っていない.

概して, 従来の生体内熱移動方程式に関しては, 運 動量方程式とリンクせずにエネルギ方程式単独で現象 を記述するものであり, 血流の速度場にはそれほど関 心が払われていないといえる。しかしながら，血流は 生体内体温調節において重要な役割を果たすものと考 えられる，例えば，人体まわりの環境温度が低い場合 には, 血管の収縮が生じ体表面近傍の静脈内の血流が 減少し, 人体から周囲環境への熱移動が抑制される. 逆に, 環境温度が高い場合には, 血管の膨張が生じ体 表面近傍の静脈内の血流が増加し, 人体から周囲環境 への熱移動が促進される.このような生体内熱移動現 象を予測するためには, 運動量方程式とリンクした生 体内熱移動方程式が必要となる。さらに, 従来の血液 の流れに対する研究(4) においては, ミクロな視点から 血管内の血液のレオロジーは詳細に議論されているも のの, ミクロな速度場の挙動を反映するマクロな運動 量方程式については議論されていない. しかしなが ら, 生体内エネルギ方程式とリンクさせる場合には, ミクロな速度場よりむしろマクロな速度場が必要とな る. 
本研究では, 多孔質のマクロな輸送方程式を導出す るために用いられる局所体積平均の概念(5) を, ミクロ な生体内速度扔よび温度場に適用し, マクロな生体内 熱移動方程式を構築していく. 局所体積平均の概念を 生体内熱移動方程式の導出に適用するという試みは, 著者らの研究(6), そして最近では中山らの研究(7)に認 められる. 局所体積平均の概念を導入することによ り, 生体内熱移動方程式中に動脈(あるいは静脈) -組 織間の熱伝達を表す項がもたらされるのであるが, 温 度などの界面物理量の取り扱いが不分明であるため, 生体内熱移動方程式において重要な役割を果たす界面 熱伝達機構のモデリングは十分であるとは言えない. そこで, 本研究では, 生体内熱移動方程式を構築する にあたり, 組織を多孔質近似し, 高津・増岡( ${ }^{(8)}$ による 流体一多孔質界面境界条件を適用することにより動脈 (あるいは静脈) -組織界面物理量を決定し, 界面熱伝 達機構を明らかにしていく.

\section{2. おもな記号}

$A_{a t}$ : 検査体積 $V$ における動脈-組織相界面の面積 $\mathrm{m}^{2}$

$A_{v t}$ : 検査体積 $V$ における静脈-組織相界面の面積 $\mathrm{m}^{2}$

$a_{a t}$ : 動脈-組織相界面の比面積 $\equiv A_{a t} / V_{a} \quad \mathrm{~m}^{-1}$

$a_{v t}$ : 静脈一組織相界面の比面積 $\equiv A_{v t} / V_{v} \quad \mathrm{~m}^{-1}$

$c_{b}:$ 血液の比熱 $\mathrm{J} /(\mathrm{kg} \cdot \mathrm{K})$

$c_{t}:$ 組織の比熱 $\mathrm{J} /(\mathrm{kg} \cdot \mathrm{K})$

$d_{a}:$ 動脈の直径 $\mathrm{m}$

$d_{v}:$ 静脈の直径 $\mathrm{m}$

$h:$ 熱伝達率 $\mathrm{W} /\left(\mathrm{m}^{2} \cdot \mathrm{K}\right)$

$k:$ 組織の透過率 $\mathrm{m}^{2}$

$K$ : 熱通過率 $\mathrm{W} /\left(\mathrm{m}^{2} \cdot \mathrm{K}\right)$

$\boldsymbol{n}$ : 動脈-組織相もしくは静脈-組織相界面での単 位法線ベクトル (図 1 参照)

$P$ : 圧力 $\mathrm{Pa}$

$P e:$ ペクレ数

$Q:$ 組織の単位体積単位時間あたりの代謝熱 $\mathrm{W} / \mathrm{m}^{3}$

$r:$ 動脈・静脈相の半径方向 $\mathrm{m}$

$t:$ 時間 $\mathrm{s}$

$T:$ 温度 $\mathrm{K}$

$u:$ 速度 $\mathrm{m} / \mathrm{s}$

$\boldsymbol{u}:$ 速度ベクトル $\mathrm{m} / \mathrm{s}$

$V:$ 検査体積 $\equiv V_{a}+V_{v}+V_{t} \quad \mathrm{~m}^{3}$

$V_{a}$ : 検查体積 $V$ に打ける動脈相体積 $\mathrm{m}^{3}$

$V_{v}$ : 検查体積 $V$ における静脈相体積 $\mathrm{m}^{3}$

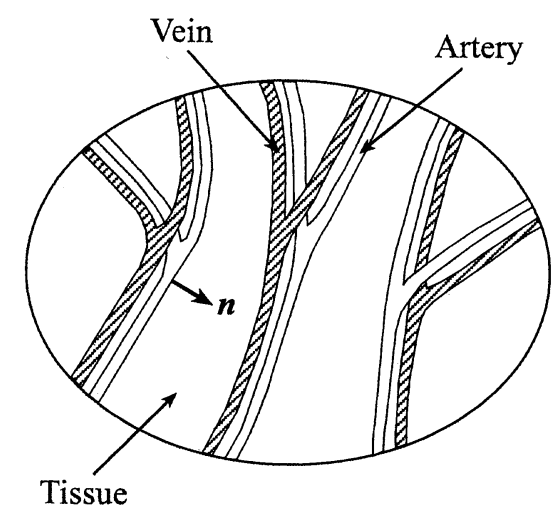

Fig. 1 Vascular network

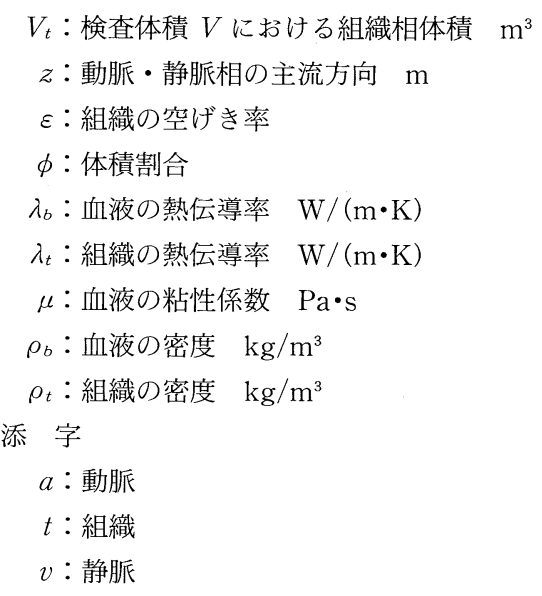

\section{3. 局所体積平均}

Weinbaum-Jiji ${ }^{(2)}$ にっって提唱された血管網のモ デルにおいては, 動脈と静脈は対を成し, 対向流とし て取り扱われている。本研究に扔いても, 図1に示す ように, 検查体積 $V$ においては, 対向流を成す動脈と 静脈の対が存在する血管網を取り扱う。

生体内輸送方程式を導出するにあたり, 局所体積平 均処理 ${ }^{(5)}$ につて簡単に述べておく.まず, 検查体積 $V$ に占める動脈・静脈㧍よび組織の体積割合に関して,

$$
\phi_{a} \equiv \frac{V_{a}}{V}, \quad \phi_{v} \equiv \frac{V_{v}}{V}, \quad \phi_{t} \equiv \frac{V_{t}}{V}
$$

とし, 動脈・静脈および組織の各相における物理量 $B$ の局所体積平均を

$$
\left.\begin{array}{rl}
\langle B\rangle^{a} & \equiv \frac{1}{V_{a}} \int_{V_{a}} B d V, \quad\langle B\rangle^{v} \equiv \frac{1}{V_{v}} \int_{V_{v}} B d V \\
\langle B\rangle^{t} & \equiv \frac{1}{V_{t}} \int_{V_{t}} B d V
\end{array}\right\}
$$


と定義する。また，動脈と静脈は吻合しないとすれば， 局所体積平均の発散・公配定理として,

$$
\left.\begin{array}{l}
\langle\operatorname{div} \boldsymbol{B}\rangle^{a}=\operatorname{div}\langle\boldsymbol{B}\rangle^{a}+\frac{1}{V_{a}} \int_{A a t} \boldsymbol{B} \cdot \boldsymbol{n} d A \\
\langle\operatorname{div} \boldsymbol{B}\rangle^{v}=\operatorname{div}\langle\boldsymbol{B}\rangle^{v}+\frac{1}{V_{v}} \int_{A_{v t}} \boldsymbol{B} \cdot \boldsymbol{n} d A \\
\langle\operatorname{div} \boldsymbol{B}\rangle^{t}=\operatorname{div}\langle\boldsymbol{B}\rangle^{t}-\frac{1}{V_{t}} \int_{A a t}+A_{v t} \boldsymbol{B} \cdot \boldsymbol{n} d A
\end{array}\right\}
$$

$$
\left.\begin{array}{l}
\langle\nabla B\rangle^{a}=\nabla\langle B\rangle^{a}+\frac{1}{V_{a}} \int_{A a t} B \boldsymbol{n} d A \\
\langle\nabla B\rangle^{v}=\nabla\langle B\rangle^{v}+\frac{1}{V_{v}} \int_{A_{v t}} B \boldsymbol{n} d A \\
\langle\nabla B\rangle^{t}=\nabla\langle B\rangle^{t}-\frac{1}{V_{t}} \int_{A_{a t}+A_{v t}} B \boldsymbol{n} d A
\end{array}\right\}
$$

が得られる。

\section{4. 連 続 の 式}

検查体積 $V$ での動脈・静脈および組織相において, 微視的には連続の式が成立している。

$$
\operatorname{div} \boldsymbol{u}=0
$$

なお, 組織相は多孔質近似し, 多孔質内空陌は毛細血 管に対応する.検査体積中の動脈・静脈および組織の 各相に対して上式の局所体積平均をとることにより, マクロな連続の式が得られる。すなわち, 局所体積平 均の発散定理 [式(3)] を適用すれば, 動脈および静 脈相でのマクロな連続の式は,

$$
\begin{array}{r}
\langle\operatorname{div} \boldsymbol{u}\rangle^{a}=\operatorname{div}\langle\boldsymbol{u}\rangle^{a}+\frac{1}{V_{a}} \int_{A a t} \boldsymbol{u} \cdot \boldsymbol{n} d A=0 \\
\ldots \ldots \ldots \\
\langle\operatorname{div} \boldsymbol{u}\rangle^{v}=\operatorname{div}\langle\boldsymbol{u}\rangle^{v}+\frac{1}{V_{v}} \int_{A v t} \boldsymbol{u} \cdot \boldsymbol{n} d A=0
\end{array}
$$

となり, 組織相でのマクロな連続の式は,

$$
\langle\operatorname{div} \boldsymbol{u}\rangle^{t}=\operatorname{div}\langle\boldsymbol{u}\rangle^{t}-\frac{1}{V_{t}} \int_{A a t+A v t} \boldsymbol{u} \cdot \boldsymbol{n} d A=0
$$

となる.

Weinbaum-Jiji ${ }^{(2)}$ にって提唱された血管網のモ デルでは, 動脈および静脈から派生した横断血管の分 岐を経て毛細血管に至っている，本モデルでは，動脈 および静脈(管内流近似)まわりは組織(多孔質近似)に 囲まれる系を考え, 動脈および静脈の管壁(透過壁)を 通しての組織内毛細血管への血流の流入 ・流出から, 潅流の効果を取り扱っていく. 透過壁から一様な速度 $\left(u_{r}\right)_{a t},\left(u_{r}\right)_{v t}$ で流入・流出すると仮定すれば,

$$
\begin{aligned}
& \frac{1}{V_{a}} \int_{A a t} \boldsymbol{u} \cdot \boldsymbol{n} d A=\left(u_{r}\right)_{a t} \frac{A_{a t}}{V_{a}}=\left(u_{r}\right)_{a t} a_{a t} \\
& \ldots \ldots \ldots \ldots \\
& \frac{1}{V_{v}} \int_{A v t} \boldsymbol{u} \cdot \boldsymbol{n} d A=\left(u_{r}\right)_{v t} \frac{A_{v t}}{V_{v}}=\left(u_{r}\right)_{v t} a_{v t}
\end{aligned}
$$

なお，上式に関しては, 動脈ならびに静脈相の占める 体積に対して局所体積平均処理を行っているため, 検 査体積中に動脈ならびに静脈血管が複数存在したとし ても, 動脈ならびに静脈相の支配方程式においては単 管に扮ける平均速度場を取り扱うことになる。また， $a_{a t}, a_{v t}$ は界面の比面積(単位体積あたりの界面の面 積)であり, 動脈および静脈を円管で近似するならば,

$$
a_{a t}=\frac{4}{d_{a}}, \quad a_{v t}=\frac{4}{d_{v}}
$$

となる.

数值解析などにおいては, 四肢などの体の部位は円 筒座標系で表され, 動脈および静脈内血流の主流方向 は軸方向として取り扱われる(3).そこで, 動脈および 静脈相内の微視的流れを, 軸方向 ( $z$ 方向) が主流とな る管内 1 次元流として取り扱えば, 動脈および静脈相 でのマクロな連続の式は, 次式で表される.

$$
\begin{aligned}
& \frac{\partial\left\langle u_{z}\right\rangle^{a}}{\partial z}=-\left(u_{r}\right)_{a t} a_{a t}=\text { const. } \\
& \frac{\partial\left\langle u_{z}\right\rangle^{v}}{\partial z}=-\left(u_{r}\right)_{v t} a_{v t}=\text { const. }
\end{aligned}
$$

なお, 本研究では, 血流場によってもたらされるエン タルピ輸送の基本メカニズムを明らかにすることを主 眼としており, 先ずは流入・流出 $\left(u_{r}\right)_{a t},\left(u_{r}\right)_{v t}$ は一 定として取り扱う生体血流モデルを展開していく. 一 方, 動脈一組織相ならびに静脈一組織相界面において, 血流の流入・流出速度が連続するという条件より, 組 織相でのマクロな連続の式として次式が得られる.

$$
\operatorname{div}\langle\boldsymbol{u}\rangle^{t}+\frac{1}{\phi_{t}}\left[\phi_{a} \frac{\partial\left\langle u_{z}\right\rangle^{a}}{\partial z}+\phi_{v} \frac{\partial\left\langle u_{z}\right\rangle^{v}}{\partial z}\right]=0
$$

上式左辺第 2 項および第 3 項に関して, 単管における 動脈およびに静脈相潅流の効果は, 体積比 $\phi_{a} / \phi_{t}$, $\phi_{v} / \phi_{t}$ を考慮することにより, 一様なものとして組織 相では取り扱われている。

\section{5. 運動量方程式}

多孔質として取り扱う組織相では，微視的すなわち 検查体積 $V$ においてはDarcy 則 ${ }^{(9)}$ が成立していると する.

$$
\frac{\rho_{b}}{\varepsilon} \frac{\partial \boldsymbol{u}}{\partial t}=-\nabla P-\frac{\mu}{k} \boldsymbol{u}
$$

上式の局所体積平均をとることにより, マクロな運動 
量方程式が得られる.

$$
\frac{\rho_{b}}{\varepsilon} \frac{\partial\langle\boldsymbol{u}\rangle^{t}}{\partial t}=-\nabla\langle P\rangle^{t}-\frac{1}{V_{t}} \int_{A a t+A v t} P \boldsymbol{n} d A-\frac{\mu}{k}\langle\boldsymbol{u}\rangle^{t}
$$

上式右辺第 2 項の管まわりの形状抵抗は, 管壁まわり の圧力分布を一様とし，

$$
\frac{1}{V_{t}} \int_{A a t+A v t} P \boldsymbol{n} d A=\boldsymbol{O}
$$

と取り扱う。すなわち, 組織相でのマクロな運動量方 程式は,

$$
\frac{\rho_{b}}{\varepsilon} \frac{\partial\langle\boldsymbol{u}\rangle^{t}}{\partial t}=-\nabla\langle P\rangle^{t}-\frac{\mu}{k}\langle\boldsymbol{u}\rangle^{t}
$$

となる.

\section{6. エネルギ方程式}

検查体積 $V$ での動脈および静脈相において, 微視 的観点からエネルギ方程式を取り扱う。

$$
\begin{aligned}
& \rho_{b} c_{b}\left[\frac{\partial T}{\partial t}+\operatorname{div}(\boldsymbol{u} T)\right]=-\operatorname{div} \boldsymbol{q} \\
& \boldsymbol{q}=-\lambda_{b} D T \quad \ldots \ldots \ldots \ldots \ldots \ldots \ldots \ldots \ldots \ldots \ldots \ldots
\end{aligned}
$$

動脈㧍よび静脈相に対して上式の局所体積平均をとる ことにより, マクロなエネルギ方程式が得られる.

$$
\begin{gathered}
\rho_{b} c_{b}\left[\frac{\partial\langle T\rangle^{a}}{\partial t}+\operatorname{div}\langle\boldsymbol{u} T\rangle^{a}+\frac{1}{V_{a}} \int_{A a t}(\boldsymbol{u} \dot{T}) \cdot \boldsymbol{n} d A\right] \\
=-\operatorname{div}\langle\boldsymbol{q}\rangle^{a}-\frac{1}{V_{a}} \int_{A a t} \boldsymbol{q} \cdot \boldsymbol{n} d A \cdots \ldots \ldots \ldots(21) \\
\rho_{b} c_{b}\left[\frac{\partial\langle T\rangle^{v}}{\partial t}+\operatorname{div}\langle\boldsymbol{u} T\rangle^{v}+\frac{1}{V_{v}} \int_{A_{v t}}(\boldsymbol{u} T) \cdot \boldsymbol{n} d A\right] \\
=-\operatorname{div}\langle\boldsymbol{q}\rangle^{v}-\frac{1}{V_{v}} \int_{A v t} \boldsymbol{q} \cdot \boldsymbol{n} d A \cdots \cdots \cdots(22)
\end{gathered}
$$

マクロな動脈相エネルギ方程式(21)に関して, $z$ 方 向の周期性を考慮すれば(10), 左辺第 2 項は,

$$
\operatorname{div}\langle\boldsymbol{u} T\rangle^{a}=\frac{\partial\left[\left\langle u_{z}\right\rangle^{a}\langle T\rangle^{a}\right]}{\partial z}
$$

となる. 式(21)左辺第 3 項に関して，管壁は透過壁で あることを考慮すれば, マクロな連続の式を用いて， 次のように表される.

$$
\frac{1}{V_{a}} \int_{A a t}(\boldsymbol{u} T) \cdot \boldsymbol{n} d A=-(T)_{a t} \frac{\partial\left\langle u_{z}\right\rangle^{a}}{\partial z}
$$

ここで, $(T)_{a t}$ は, 動脈-組織相界面での温度である。 式 (20)の熱流束べクトルの局所体積平均は,

$$
\langle\boldsymbol{q}\rangle^{a}=-\lambda_{b}\left|\nabla\langle T\rangle^{a}+\frac{1}{V_{a}} \int_{\text {Aat }} \operatorname{Tn} d A\right|
$$

と与えられる。管壁まわりの温度分布が一様であると 仮定し，

$$
\frac{1}{V_{a}} \int_{\text {Aat }} \operatorname{Tn} d A=\boldsymbol{O}
$$

と取り扱えば, 式(21)右辺第 1 項は,

$$
\operatorname{div}\langle\boldsymbol{q}\rangle^{a}=-\lambda_{b} \frac{\partial^{2}\langle T\rangle^{a}}{\partial z^{2}}
$$

となる、さらに, 式(21)右辺第 2 項は,

$$
\frac{1}{V_{a}} \int_{A a t} \boldsymbol{q} \cdot \boldsymbol{n} d A=-\lambda_{b}\left(\frac{\partial T}{\partial r}\right)_{a t} a_{a t}
$$

ここで, $(\partial T / \partial r)_{a t}$ は, 動脈-組織相界面での温度勾配 である。

すなわち，動脈相でのマクロなエネルギ方程式は，

$$
\begin{gathered}
\rho_{b} c_{b}\left[\frac{\partial\langle T\rangle^{a}}{\partial t}+\frac{\partial\left[\left\langle u_{z}\right\rangle^{a}\langle T\rangle^{a}\right]}{\partial z}-(T)_{a t} \frac{\partial\left\langle u_{z}\right\rangle^{a}}{\partial z}\right] \\
\quad=\lambda_{b} \frac{\partial^{2}\langle T\rangle^{a}}{\partial z^{2}}+\lambda_{b}\left(\frac{\partial T}{\partial r}\right)_{a t} a_{a t} \cdots \cdots \cdots \cdots \cdots \cdots(29)
\end{gathered}
$$

となる。同様に, 静脈相でのマクロなエネルギ方程式 は, 次式で表される。

$$
\begin{gathered}
\rho_{b} c_{b}\left[\frac{\partial\langle T\rangle^{v}}{\partial t}+\frac{\partial\left[\left\langle u_{z}\right\rangle^{v}\langle T\rangle^{v}\right]}{\partial z}-(T)_{v t} \frac{\partial\left\langle u_{z}\right\rangle^{v}}{\partial z}\right] \\
=\lambda_{b} \frac{\partial^{2}\langle T\rangle^{v}}{\partial z^{2}}+\lambda_{b}\left(\frac{\partial T}{\partial r}\right)_{v t} a_{v t} \cdots \cdots \cdots \cdots \cdots(30)
\end{gathered}
$$

ここで, $(T)_{v t}$ は静脈一組織相界面での温度, $(\partial T / \partial r)_{v t}$ は静脈一組織相界面での温度勾配である。

一方，多孔質として取り扱う組織相では，微視的す なわち検査体積 $V$ において成立するエネルギ方程式 は，次式で表される。

$$
\begin{aligned}
& \rho_{t} c_{t} \frac{\partial T}{\partial t}+\rho_{b} c_{b} \operatorname{div}(\boldsymbol{u} T)=-\operatorname{div} \boldsymbol{q}_{t}+Q \cdots \\
& \boldsymbol{q}_{t}=-\lambda_{t} \nabla T \ldots \ldots \ldots \ldots \ldots \ldots \ldots \ldots \ldots \ldots \ldots \ldots \ldots \ldots \ldots \ldots \ldots \ldots \ldots \ldots
\end{aligned}
$$

組織の代謝熱 $Q$ は, 検査体積 $V$ において一様である とする，上式の局所体積平均をとることにより，マク ロな組織相エネルギ方程式が得られる.

$$
\begin{aligned}
\rho_{t} c_{t} & \frac{\partial\langle T\rangle^{t}}{\partial t}+\rho_{b} c_{b}\left[\operatorname{div}\langle\boldsymbol{u} T\rangle^{t}\right. \\
& \left.-\frac{1}{V_{t}} \int_{A_{a t}+A_{v t}}(\boldsymbol{u} T) \cdot \boldsymbol{n} d A\right] \\
& =-\operatorname{div}\left\langle\boldsymbol{q}_{t}\right\rangle^{t}+\frac{1}{V_{t}} \int_{A a t+A_{v t}} \boldsymbol{q}_{t} \cdot \boldsymbol{n} d A+Q
\end{aligned}
$$

マクロな組織相エネルギ方程式(33)に関して, 多孔 質近似された組織相内部幾何構造の周期性を考慮すれ ば(10), 左辺第 2 項は,

$$
\operatorname{div}\langle\boldsymbol{u} T\rangle^{t}=\operatorname{div}\left\{\langle\boldsymbol{u}\rangle^{t}\langle T\rangle^{t}\right\}
$$

となる。動脈一組織相界面および静脈一組織相界面にお いて, エンタルピ輸送は連続することになるので, 式 （24）などを用いて, 式(33)左辺第 3 項は,

$$
\begin{aligned}
& \frac{1}{V_{t}} \int_{A_{a t}+A_{v t}}(\boldsymbol{u} T) \cdot \boldsymbol{n} d A \\
& \quad=-\frac{1}{\phi_{t}}\left[\phi_{a}(T)_{a t} \frac{\partial\left\langle u_{z}\right\rangle^{a}}{\partial z}+\phi_{v}(T)_{v t} \frac{\partial\left\langle u_{z}\right\rangle^{v}}{\partial z}\right]
\end{aligned}
$$

となる. 式(32)の熱流束ベクトルの局所体積平均は, 


$$
\left\langle\boldsymbol{q}_{t}\right\rangle^{t}=-\lambda_{t}\left[D\langle T\rangle^{t}-\frac{1}{V_{t}} \int_{A_{a t}+A_{v t}} \operatorname{Tn} d A\right]
$$

と与えられ, 動脈-組織相界面および静脈一組織相界面 において, 温度は連続することになるので [式(26)参 照],

$$
\frac{1}{V_{t}} \int_{A a t+A v t} \operatorname{Tn} d A=\boldsymbol{O}
$$

が得られ，式(33)右辺第 1 項は，

$$
\operatorname{div}\left\langle\boldsymbol{q}_{t}\right\rangle^{t}=-\lambda_{t} \nabla^{2}\langle T\rangle^{t}
$$

となる。動脈一組織相界面および静脈一組織相界面にお いて, 熱流束べクトルは連続することになるので [式 (28) 参照], 式 (33) 右辺第 2 項は,

$$
\begin{aligned}
& \frac{1}{V_{t}} \int_{A a t+A v t} \boldsymbol{q}_{t} \cdot \boldsymbol{n} d A=-\frac{\lambda_{b}}{\phi_{t}}\left[\phi_{a}\left(\frac{\partial T}{\partial r}\right)_{a t} a_{a t}\right. \\
& \left.\quad+\phi_{v}\left(\frac{\partial T}{\partial r}\right)_{v t} a_{v t}\right] \ldots \ldots \ldots \ldots \ldots \ldots \ldots \ldots \ldots \ldots \ldots \ldots \ldots \ldots \ldots \ldots
\end{aligned}
$$

となる.

すなわち, 組織相でのマクロなエネルギ方程式は,

$$
\begin{aligned}
\rho_{t} c_{t} \frac{\partial\langle T\rangle^{t}}{\partial t}+\rho_{b} c_{b} \operatorname{div}\left\{\langle\boldsymbol{u}\rangle^{t}\langle T\rangle^{t}\right\} \\
+\frac{\rho_{b} c_{b}}{\phi_{t}}\left[\phi_{a}(T)_{a t} \frac{\partial\left\langle u_{z}\right\rangle^{a}}{\partial z}+\phi_{v}(T)_{v t} \frac{\partial\left\langle u_{z}\right\rangle^{v}}{\partial z}\right] \\
\quad=\lambda_{t} \nabla^{2}\langle T\rangle^{t}-\frac{\lambda_{b}}{\phi_{t}}\left[\phi_{a}\left(\frac{\partial T}{\partial r}\right)_{a t} a_{a t}\right. \\
\left.+\phi_{v}\left(\frac{\partial T}{\partial r}\right)_{v t} a_{v t}\right]+Q \cdots \cdots \cdots \cdots \cdots \cdots \cdots(40)
\end{aligned}
$$

となる。

\section{7. 流体-多孔質界面}

マクロな支配方程式を導出にあたり，動脈および静 脈相を管内 1 次元流で取り扱うとともに, 組織相を多 孔質近似した。そこで, 流体一多孔質界面の境界条件 を適用することにより，動脈および静脈相のエネルギ 方程式に含まれる界面物理量を導出する.

検查体積 $V$ における組織相の温度分布に着目すれ ば, 動脈相もしくは静脈相との界面近傍で温度勾配を 有するものの, 組織の代謝熱 $Q$ の効果により一様な 温度分布になると考えられる. そこで, 組織相の多孔 質近似に際し, 流体-多孔質界面(動脈-組織相界面も しくは静脈一組織相界面)において温度スリップが生じ るものとして取り扱う。流体一多孔質界面において温 度スリップが生じる場合の熱流束のつりあいに関する 境界条件は, 高津・増岡 ${ }^{(8)}$ により次式が提案されてい る.

$$
\lambda_{f}\left(\frac{\partial T}{\partial r}\right)_{f}=\lambda_{e} \frac{(T)_{f}-(T)_{p}}{l_{t}}
$$

ここで, $(\partial T / \partial r)_{f}$ は流体-多孔質界面流体層側温度勾
配， $(T)_{f}$ は流体-多孔質界面流体層側温度， $(T)_{p}$ は流 体-多孔質界面多孔質層側温度, $\lambda_{f}$ は流体層の熱伝導 率, $\lambda_{e}$ は多孔質層の有効熱伝導率である. 流体層から 多孔質層内への温度変化の浸透深さ $l_{t}$ は,

$$
l_{t}=\sqrt{\frac{1}{h^{\prime}\left[\frac{1}{\varepsilon \lambda_{f}}+\frac{1}{(1-\varepsilon) \lambda_{s}}\right]}}
$$

で表され, $h^{\prime}$ は多孔質層内の流体相と固体相間の熱伝 達率， $\lambda_{s}$ は多孔質層内固体相の熱伝導率である。検査 体積 $V$ において組織相温度分布がほぼ一様であると すれば, 多孔質(組織相)での温度は, $(T)_{p} \approx\langle T\rangle^{t}$ と 近似できる。ささらに, 動脈抢よび静脈内熱伝達 $h_{a}, h_{v}$ を導入すれば, 次の関係式が得られる.

$$
\begin{aligned}
- & \lambda_{b}\left(\frac{\partial T}{\partial r}\right)_{a t}=\lambda_{t} \frac{(T)_{a t}-\langle T\rangle^{t}}{l_{t}} \\
& =h_{a}\left[\langle T\rangle^{a}-(T)_{a t}\right] \cdots \cdots \ldots \ldots \ldots \\
- & \lambda_{b}\left(\frac{\partial T}{\partial r}\right)_{v t}=\lambda_{t} \frac{(T)_{v t}-\langle T\rangle^{t}}{l_{t}} \\
& =h_{v}\left[\langle T\rangle^{v}-(T)_{v t}\right] \cdots \cdots \cdots \cdots \cdots
\end{aligned}
$$

なお, 式(41)に対して上式では負の符号が導入されて いるのは, 座標系の取り扱いの違いによるものであ る.

式(43)および式(44)より, 界面温度は次のように表 される。

$$
\begin{aligned}
& (T)_{a t}=\frac{\frac{l_{t}}{\lambda_{t}}\langle T\rangle^{a}+\frac{1}{h_{a}}\langle T\rangle^{t}}{\frac{1}{K_{a}}} \\
& (T)_{v t}=\frac{\frac{l_{t}}{\lambda_{t}}\langle T\rangle^{v}+\frac{1}{h_{v}}\langle T\rangle^{t}}{\frac{1}{K_{v}}}
\end{aligned}
$$

ここで，熱通過率 $K_{a}, K_{v}$ は,

$$
\begin{aligned}
& \frac{1}{K_{a}} \equiv \frac{1}{h_{a}}+\frac{l_{t}}{\lambda_{t}} \\
& \frac{1}{K_{v}} \equiv \frac{1}{h_{v}}+\frac{l_{t}}{\lambda_{t}}
\end{aligned}
$$

と定義している．すなわち, 動脈相および静脈相での マクロなエネルギ方程式に界面物理量を代入すれば,

$$
\begin{aligned}
& \rho_{b} c_{b}\left[\frac{\partial\langle T\rangle^{a}}{\partial t}+\left\langle u_{z}\right\rangle^{a} \frac{\partial\langle T\rangle^{a}}{\partial z}\right] \\
& =\lambda_{b} \frac{\partial^{2}\langle T\rangle^{a}}{\partial z^{2}}+\frac{K_{a}}{h_{a}} \rho_{b} c_{b}\left(u_{r}\right)_{a t} \\
& \times\left[\langle T\rangle^{a}-\langle T\rangle^{t}\right] a_{a t}-K_{a}\left[\langle T\rangle^{a}-\langle T\rangle^{t}\right] a_{a t} \\
& \quad \cdots \cdots \cdots \cdots(49) \\
& \rho_{b} c_{b}\left[\frac{\partial\langle T\rangle^{v}}{\partial t}+\left\langle u_{z}\right\rangle^{v} \frac{\partial\langle T\rangle^{v}}{\partial z}\right] \\
& =\lambda_{b} \frac{\partial^{2}\langle T\rangle^{v}}{\partial z^{2}}+\frac{K_{v}}{h_{v}} \rho_{b} c_{b}\left(u_{r}\right)_{v t} \\
& \quad \times\left[\langle T\rangle^{v}-\langle T\rangle^{t}\right] a_{v t}-K_{v}\left[\langle T\rangle^{v}-\langle T\rangle^{t}\right] a_{v t}
\end{aligned}
$$


が得られる。一方, 組織相でのマクロなエネルギ方程 式において，マクロな連続の式 [式(14)］を考慮すれ ば, 次式が得られる。

$$
\begin{aligned}
& \rho_{t} c_{t} \frac{\partial\langle T\rangle^{t}}{\partial t}+\rho_{b} C_{b}\langle\boldsymbol{u}\rangle^{t} \cdot \nabla\langle T\rangle^{t}=\lambda_{t} \nabla^{2}\langle T\rangle^{t} \\
& +\frac{\phi_{a}}{\phi_{t}} \lambda_{a} / l_{t} \rho_{b} c_{b}\left(u_{r}\right)_{a t}\left[\langle T\rangle^{a}-\langle T\rangle^{t}\right] a_{a t} \\
& +\frac{\phi_{v}}{\phi_{t}} \frac{K_{v}}{\lambda_{t} / l_{t}} \rho_{b} c_{b}\left(u_{r}\right)_{v t}\left[\langle T\rangle^{v}-\langle T\rangle^{t}\right] a_{v t} \\
& +\frac{\phi_{a}}{\phi_{t}} K_{a}\left[\langle T\rangle^{a}-\langle T\rangle^{t}\right] a_{a t} \\
& +\frac{\phi_{v}}{\phi_{t}} K_{v}\left[\langle T\rangle^{v}-\langle T\rangle^{t}\right] a_{v t}+Q
\end{aligned}
$$

ここで, 上式に導入されたパラメータについて少し言 及して抢く。従来の生体内熱移動方程式(1)(2) と比較し て, 新たな熱物性值として血液の熱伝導率 $\lambda_{b}$ が導入 されているが, 例えば文献(11)を参照して求められ る. 次に, 熱通過率 $K_{a}, K_{v}$ を構成するパラメーター に着目する。動脈抢よび静脈内熱伝達率 $h_{a}, h_{v}$ に関 しては, 動脈拧よび静脈の管壁 (透過壁) を通して組織 内毛細血管への血流の流入 ・流出速度 $\left(u_{r}\right)_{a t},\left(u_{r}\right)_{v t}$ が十分小さく，層流として取り扱える場合には，円管 内ヌセルト数 $h_{a} d_{a} / \lambda_{b}, h_{v} d_{v} / \lambda_{b}$ は 4 程度の值をとると 考元られ。，一方，組織相内一の温度変化の浸透深さ $l_{t}$ に関しては, 今後実験などにより決定されるべきパ ラメーターと考えているが, バルク(平均)温度測定と なるため, Weinbaum-Jiji の式(2)で必要となる血管 網の幾何形状の測定に比べると検証は容易と考えられ る.

本研究で導かれた組織相でのマクロなエネルギ方程 式と従来の生体内熱移動方程式の関連について言及し ておく. 例えば, 式(51)において, 静脈相温度と組織 相温度が等しければ,

$$
\langle T\rangle^{v}=\langle T\rangle^{t} \cdots
$$

次式が得られる.

$$
\begin{gathered}
\rho_{t} C_{t} \frac{\partial\langle T\rangle^{t}}{\partial t}+\rho_{b} C_{b}\langle\boldsymbol{u}\rangle^{t} \cdot \nabla\langle T\rangle^{t}=\lambda_{t} \nabla^{2}\langle T\rangle^{t} \\
+\frac{\phi_{a}}{\phi_{t}} \frac{K_{a}}{\lambda_{t} / l_{t}} \rho_{b} C_{b}\left(u_{r}\right)_{a t}\left[\langle T\rangle^{a}-\langle T\rangle^{t}\right] a_{a t} \\
+\frac{\phi_{a}}{\phi_{t}} K_{a}\left[\langle T\rangle^{a}-\langle T\rangle^{t}\right] a_{a t}+Q \cdots \cdots \cdots \cdots
\end{gathered}
$$

上式右辺第 2 項は, Pennes の式(1)における血液潅流 によるエンタルピ輸送を表し, 組織単位体積あたりの 血液流量 $w_{b}$ は,

$$
w_{b}=\frac{\phi_{a}}{\phi_{t}} \frac{K_{a}}{\lambda_{t} / l_{t}}\left(u_{r}\right)_{a t} a_{a t}
$$

と与えられる.また, 式(53)右辺第 3 項は, 動脈-組織 界面における熱伝導による熱移動を表し, 静脈相温度 と組織相温度がほぼ等しいとすれば, 対向流による熱
交換の項とみなせる。なお，従来の生体内熱移動方程 式に関しては, 式(53)左辺第 2 項に対してモデル化が 行われ, Pennesの式(1)では等方発熱項に還元され, Weinbaum-Jiji の式(2)では血管幾何構造を考慮した 対向流による熱交換項に還元されている。しかしなが ら, 動脈(あるいは静脈) と組織の相互作用は, 界面を 通して行われるので, 式(53)右辺第 2 および 3 項のよ うに動脈(あるいは静脈) -組織界面における熱移動と して直接表現するのが適切と考えられる。また, 式 (53) 左辺第 2 項は, 組織に温度分布が形成されること によりもたらされるエンタルピー輸送であり，組織内 平均速度が零と近似できる場合には，無視できる。一 方, 生体内熱移動方程式に式 (53)左辺第 2 項を導入す れば，血管の収縮・膨張などによる体温調節機構のよ うな血流場が関連する問題を取り扱元，生体内熱移動 方程式の適用範囲が広がると考えられる。

組織単位体積あたりの血液流量 $w_{b}$ を次のように記 述すれば, 動脈一組織界面に扔ける熱伝導による熱移 動の寄与を Pennes の式に導入することができる.

$$
w_{b}=\frac{\phi_{a}}{\phi_{t}} \frac{K_{a}}{\lambda_{f} / l_{t}}\left(1+\frac{1}{P e_{a}}\right)\left(u_{r}\right)_{a t} a_{a t}
$$

ここで, ペクレ数 $P e_{a}$ は次式で定義されている.

$$
P e_{a} \equiv \frac{\left(u_{r}\right)_{a t} l_{t}}{\lambda_{t} /\left(\rho_{b} c_{b}\right)}
$$

ペクレ数 $P e_{a}$ のオーダーに関連して, 動脈の管壁 (透 過壁)を通して組織内毛細血管への血流の流出速度 $\left(u_{r}\right)_{a t}$ はそれほど大きくならないと考えられる。ま た, 浸透深さ $l_{t}$ についても, 毛細血管で構成される組 織内では細管効果により式(42)中の $h^{\prime}$ は十分大きく なるため, 浸透深さ $l_{t}$ は十分大きな值とはならない. すなわち, ペクレ数 $P e_{a} \gg 1$ とはなり元ず, 生体内熱 移動方程式のモデル化に際し, 動脈-組織内界面にお ける熱伝導の効果は無視できないことになる。

\section{8. 結言}

本研究では, 動脈抢よび静脈相を管内 1 次元流で近 似するとともに, 組織相を多孔質近似することにより， 生体内輸送現象を詳細に検討し, 速度場を考慮した生 体内熱移動方程式を理論的に導出した. 特に, 動脈 (あるいは静脈) と組織間の熱伝達機構を明らかにし, 生体内熱移動方程式中の組織単位体積あたりの血液流 量 $w_{b}$ ならびに動脈(あるいは静脈)一組織界面におけ る熱伝導に関与する基本パラメーターを明確にした。

\section{文献}

(1) Pennes, H. H., Analysis of Tissue and Arterial Blood Temperatures in the Resting Human Forearm, Journal 
of Applied Physiology, Vol. 1 (1948), pp. 93-122.

(2) Weinbaum, S. and Jiji, L. M., A New Simplified Bioheat Equation for the Effect of Blood Flow on Local Average Tissue Temperature, Transactions of the ASME, Journal of Biomechanical Engineering, Vol. 107 (1985), pp. 131-139.

(3) Yokoyama, S., Heat Transfer in Biology (in Japanese), (1993), p. 87, Hokkaido University Press.

(4) The Japan Society of Mechanical Engineers ed., Biomechanics (in Japanese), (1991), p. 143, Ohmsha, Ltd.

(5) Slattery, J.C., Advanced Transport Phenomena, (1999), p. 197, Cambridge University Press.

(6) Takatsu, Y., Masuoka, T., Tamura, M. and Kohri, I., New Bio Heat Equation Coupled with Momentum Equation, Proceeding 36th National Heat Transfer Symposium of Japan, Vol. 2 (1999), pp. 443-444.

(7) Nakayama, A., Kuwahara, F. and Motoyama, H., Derivation of the Volume-Averaged Governing Equa- tions for Bioheat Transfer, Proceeding 44th National Heat Transfer Symposium of Japan, Vol. 1 (2007), pp. 29-30.

(8) Takatsu, Y. and Masuoka, T., Slip Boundary Condition at Interface between Porous and Fluid Layers, Transactions of the Japan Society of Mechanical Engineers, Series B, Vol. 73, No. 732 (2007), pp. 1710-1714.

(9) Nield, D. A. and Bejan, A., Convection in Porous Media, (2006), p. 8, Springer-Verlag.

(10) Takatsu, Y. and Masuoka, T., Production and Dissipation of Turbulence in Porous Media, Transactions of the Japan Society of Mechanical Engineers, Series B, Vol. 68, No. 673 (2002), pp. 2601-2605.

(11) Tanishita, K., Nagasaka, Y., Nagashima, A., Yamaguchi, T. and Sugawara, M., Measurement of Thermal Conductivity of Blood by Transient Hot Wire Method, Transactions of the Japan Society of Mechanical Engineers, Series B, Vol. 47, No. 421 (1981), pp. 1784-1791. 